\title{
Coagulation Factor VIII
}

National Cancer Institute

\section{Source}

National Cancer Institute. Coagulation Factor VIII. NCI Thesaurus. Code C16571.

Coagulation factor VIII (2351 aa, $\sim 267 \mathrm{kDa}$ ) is encoded by the human F8 gene. This protein plays a role in the modulation of coagulation factor IX activity and blood coagulation. 